\title{
Students' literature achievement: Predictors investigation research
}

\author{
Alita Arifiana Anisa \\ Graduate School of Universitas Negeri Yogyakarta \\ Jl. Colombo No. 1, Karangmalang, Depok, Sleman, Yogyakarta 55281, Indonesia \\ Email: alita.arifiana.anisa@gmail.com
}

Submitted: 22 December 2017 | Revised: 06 February 2018 | Accepted: 06 February 2018

\begin{abstract}
This research is an expost facto research which aims to find out the exsistence of the mean difference between gender in terms of achievement, and investigate the variables predicting students' achievement in literature study including the direct/indirect effect. This research involved 90 students established ramdomly as the sample. The research used the quantitative data analysis to analyze the mean difference between groups and the direct/indirect effect of the predictors. The result of this research shows that: (1) girls have higher achievement in literature study compared to boys; (2) the predictors that are statistically proven as a direct significant predictor of students' final test score are gender, second dummy variable for class and mid-term test, while the rest of predictors (except the first dummy variable of class) contribute indirectly to the prediction of students' achievement in literature study; and (3) the magnitude of the predictors might be different when they are applied in different classes.
\end{abstract}

Keywords: literature achievement, path analysis, gender, attendance

\section{How to cite item:}

Anisa, A. (2017). Students' literature achievement: Predictors investigation research. REiD (Research and Evaluation in Education), 3(2), 144-151. doi:http://dx.doi.org/10.21831/reid.v3i2.17498

\section{Introduction}

As a requirement to attain a bachelor degree in an institution in Ponorogo, East Java, Indonesia, a final research project called thesis (or skripsi in Indonesian term) has to be conducted by students. The thesis took students' time and energy, especially in reading as well as understanding the literature needed to support their idea and findings. In order to improve the students' skill in understanding and citating relevant literature and studies, the institution conducts a compulsory course aimed at assisting the students in finding, understanding, reviewing, and citating the idea from texts. The course is called Literature Study which has to be taken by every student in the institution before they take their final research or project (thesis).
In the first semester of academic year of 2016/2017, there were ten classes consisting of approximately 350 students undertaking Literature Study. During the semester, the students have to (1) attend and actively participate in 16 face-to-face meetings, and (2) comply with all of the evaluation requirements, including oject presentation and mid-term test. The issue is that although the subject is considered to be very important for the success of their final research/project, the students seemed to think that the subject was not as important as their main subjects (the subjects directly connected to their major), so their achievement in the course was not satisfactory. The unsatisfying final score leads to the stakeholders' anxiety related to the quality of the students' final research/project (thesis). The poor quality of their thesis is one of the indi- 
cations of the poor academic ability in integrating all of the knowledge that the students have earned in their four-year study.

Phye (1995) states that learning and achievement are surely related, but they are different in significant ways. People start to learn anything consciously or even unconsciously to achieve their desired objectives. For example, when you saw someone playing a doll-fishing machine and found that he never missed the doll, you were excited to know how he did such a good thing and started to observe every single thing he did in order to catch the doll. The observation you did to gain any information in doing doll fishing is a learning process and to be a good doll-fisher is your objective. After gaining information, you start to test whether the information works by challenging yourself to do doll fishing by yourself, and the result of your dollfishing test represents your achievement. It could be good (you were successful in catching the doll by using the information you have got from the learning process, i.e, observation), but it could also be not too good (you missed the doll). The achievement (either to be good or not too good) shows whether the learning process you did earlier meets your objectives.

Pritchard (2009), in Ways of Learning, mentions some definitions of learning, including: (1) a change in behaviour as a result of experience or practice, (2) the acquisition of knowledge, (3) knowledge gained through study, (4) gaining knowledge of, or skill in, something through study, teaching, instructions, or experience, (5) the process of gaining knowledge, (6) a process by which one's behaviour is changed, shaped or controlled, and (7) the individual process of constructing understanding based on the experience from wide range of sources. Thus, learning is a process in gaining knowledge through experiences and proven by behavioural changes. The experience means any kinds of experience, including educational experience through teaching and learning processes at school.

Meanwhile, achievement is what you gain from learning processes. The definition of academic achievement by the Dictionary of Education in Phye (1995) is an accomplishment or proficiency of knowledge or skill. The achievement shows the increase of the learners' knowledge after experiencing learning. One of the ways to see the learners' achievement is by seeing their changes. In order to know their achievement as a result of learning process, teachers need to conduct assessment. American Educational Research Association (AERA, 1999) in Reynolds, Livingston, and Willson (2009) mentions that in general, assessment is any systematic procedure to collect the information to make inferences about the characteristics of people. In educational issue, assessment can be defined as a procedure to gain any information about students' learning or value judgement concerning learning process through observations, ratings of performance, project or tests (Miller, Linn, \& Gronlund, 2009).

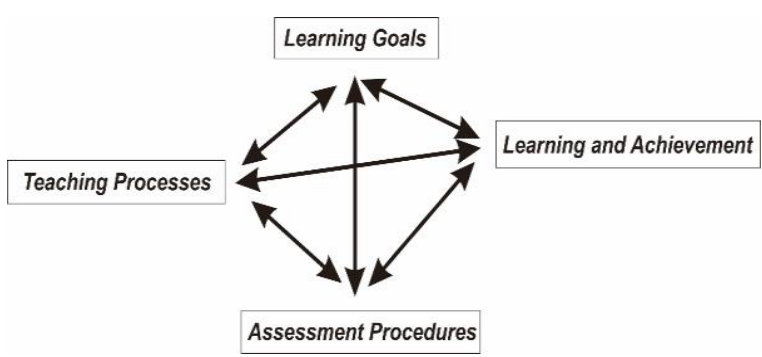

Figure 1. The relationship among learning, achievement, and assessment (Cumming \& Maxwell, 1999)

There are some procedural questions which need to be answered in conducting an assessment: First, what are the learning objectives/goals which need to be achieved? Learning leads to the changes of knowledge. Thus, the first step that the teacher needs to do to assess students' learning achievement is deciding the specific learning objectives or identifying what the teacher wants the students to master after the learning process. Although Mueller in Berg (2006) mentions that it is not easy for a teacher to write good learning objectives, it is essential to acquire a clarity of purpose, because with clear purposes in mind, assessment can be well designed to match the purposes (Phye, 1995).

Second, what kind of assessment approaches matches the learning objectives? Identification to determine the type of goals needs to be held. Is it cognitive changes 
which come as the result of content acquisition? Is it motor changes in performing specific task? Or is it behavioural changes? The identification process is important to help teachers to choose the best assessment approaches and tools to meet their teaching objectives. The assessment approaches to each learning objective are as follows. (1) Cognitive objectives include the building of knowledge base (Thorndike \& Thorndike-Christ, 2010). In order to meet the cognitive changes as a result of content acquisition type of learning objectives, various types of test can be conducted, such as multiple-choice item, matching, true or false, essay, short answer or filling in the blank tests (Phye, 1995). (2) Performance objectives cover the motor changes and how the learners perform their knowledge in the form of action/skill in doing a specific task. In order to match the performance objectives, a task that requires students to demonstrate a specific action or project is appropriate, such as playing musical instrument, using software to analyse data, constructing housing model, and making financial report. (3) Affective/behaviour objectives involve the development of attitudes, values, interest and personal or social attributes that teachers can assess through observation (and try to infer what lies behind the behaviour), peers' or teachers' rates, and also students' self-reports (Thorndike \& Thorndike-Christ, 2010).

Third, after the set of operations that requires students to perform their cognitive, performance, and attitude changes has been accomplished, it is important to set the rule to value students' responses. The rule which is called scale is crucial to decide the most suitable number that is able to represent how much the objective is existing (Thorndike \& Thorndike-Christ, 2010). There are four kinds of scale which are used in measurement theories, namely: nominal scale (the number on the scale does not refer to the amount of anything), ordinal scale (the number on the scale tells the order of specific condition without knowing how much something is less or more than something else), interval scale (each number on the scale has equal difference, zero in this scale is not an absolute zero, and ratio scale (the scale that has an absolute zero).

The educational objectives are measured by various types of instruments (the assessment tools) that are able to cover cognitive, performance, and affective objectives. The instrument is assumed to have equal amount of traits in every item. The equal differences in score indicate the equal differences in traits, and, thus, they fulfil the requirement to use interval scale. In the interval scale, the absolute zero does not exist; it is suitable to the educational issues where the students are not assumed as an empty vehicle (the base knowledge existence assumed). After setting the specific rule to value students' responses, the next step to do is scoring. The common mechanism to do a scoring is by calculating the relative achievement objective. Relative mastery involves estimating the percentage of the domain that the students have mastered. For example, when students answer eight out of ten questions correctly, it indicates that the students have mastered $80 \%$ of the domain (Thorndike \& Thorndike-Christ, 2010).

The study related to the variables which can predict the final test score is beneficial to provide the stakeholder (lecturers and academic authorities) of the institution an evidence to formulate the decision to perform a better package of treatments to assist the students in preparing themselves to face the final research through Literature Study course. By the study, the lecturers are able to decide what to be focused in order to optimize students' literature achievement. The main purpose of the study is to identify the variables that are able to predict students' achievement in Literature Study.

The study is significant since there has never been a study related to the final test score in Literature Study in Ponorogo, although the literature study is considered to be beneficial to students in conducting their final research/project (as one of the requirements to graduate from the bachelor degree). This study is able to provide the lecturers and academic authorities an empiric evidence to give an appropriate treatment to help the students to reach their optimum achievement. 


\section{Method}

\section{Population and Sample}

The population of the study was all of the students who are majoring in Islamic religion education. They took literature study course in the academic year of 2016/2017. The sample of the study was 90 students from three classes of $\mathrm{X}, \mathrm{Y}$, and $\mathrm{Z}$ who are chosen randomly.

\section{Data Variables}

The data which were employed in this research included: (1) gender, (2) classes, (3) attendance, (4) project presentation score, (5) mid-term test score, and (6) final-test score or achievement. Table 1 shows the description of the data.

\section{Research Procedures}

This research is an expost facto research which studies about the variables that occured in the past. The research employed the quantitative research approach in order to investigate two independent variables and also four dependent variables. The research covered: (1) a descriptive analysis for analyzing the frequency of the categorical data (gender and classes) and the central tendency, variance, standard deviation, skewness and kurtosis of the continuous data (attendance, project presentation, midterm test, and final test); (2) mean difference to analyze the mean difference between genders in achievement; (3) a path analysis to analyze the direct and indirect effect in predicting the independent variable, its equation and the final model; and also (4) a path analysis for each class. Meanwhile, the hypothesis of the research model analyzed is presented in Figure 2.

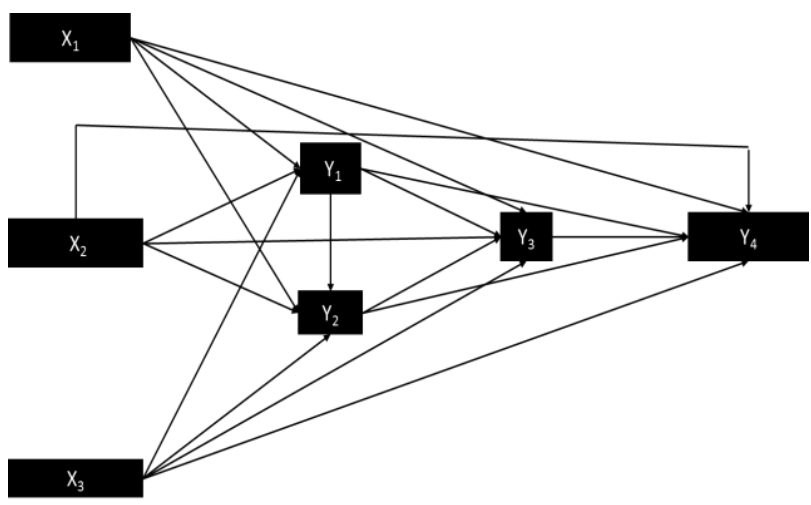

X1: Gender; X2: Classdummy1; X3: Classdummy2 Y1: Attendance; Y2: Project Presentation; Y3: Mid-term Test Y4: Final Achievement

Figure 2. Hypothesis research model

\section{Findings and Discussion}

Findings

The sample consists of 90 participants, more than half $(64.44 \%, \mathrm{n}=58)$ of the participants are girls, and $35.56 \%$ of the samples are boys $(\mathrm{n}=32)$. The samples are the students who are studying literature study in three different classes, in which $27.8 \%(\mathrm{n}=25)$ are class $\mathrm{X}$ students, $37.8 \%(\mathrm{n}=34)$ are class $\mathrm{Y}$ students, and the rest $34.4 \%(\mathrm{n}=31)$ are class Z students.

Table 1. Data descriptions

\begin{tabular}{llll}
\hline \multicolumn{1}{c}{ Data } & \multicolumn{1}{c}{ Description } & Data Type & \multicolumn{1}{c}{ Data Source } \\
\hline Gender & $\begin{array}{l}\text { 1 }=\text { Male } \\
0=\text { Female }\end{array}$ & Categorical & Student identity document \\
Classes & $1=\mathrm{X}$ & Categorical & Academic document \\
& $2=\mathrm{Y}$ & & \\
& $3=\mathrm{Z}$ & & \\
Attendance & The students' attendance in 16 meetings. & Continues & Teacher-attendance report \\
Group project presentation & The average score of group and individual & Continues & Student performance \\
& performance The score in 1 to 100. & & report \\
Mid-term test score & The score is 1-100. & Continues & Mid-term test results \\
Final test score & The score is 1-100. & Continues & Final test result \\
\hline
\end{tabular}


Figure 3 shows the distribution of the variables which are studied in this research. All of the variables are considered to be normally distributed, with the skewness of less than \pm 2.0 , and kurtosis of less than \pm 7.0 . Significantly, the data indicate that the attendance variable is ranging from 57 to 100 $(M=93.91$, $s=7.523)$, while the project variable ranges from 52 to 89 with the average score (M) of 79.74 and standard deviation (s) of 5.867. Furthermore, the data also show that the average score of the students' midtest score is 71.10 (which is ranging from 50 to $98, \mathrm{~s}=11.138$ ), and the final test score is ranging from 50 to 100 (in which $\mathrm{M}=78.17$, $\mathrm{s}=12.002)$.
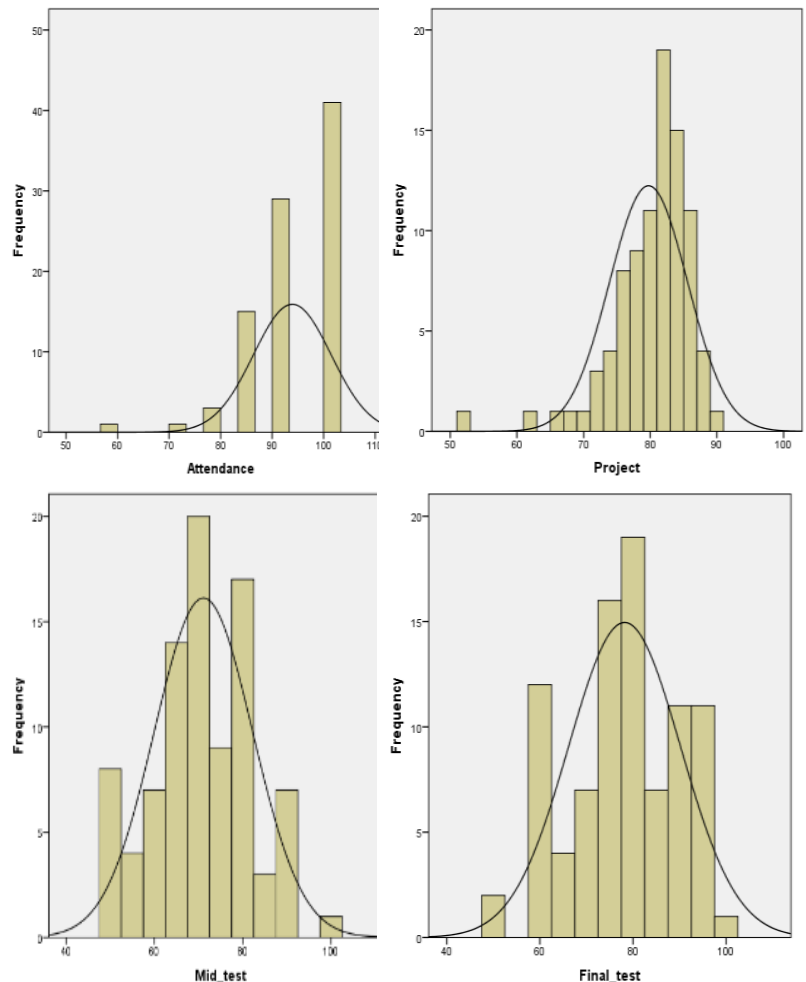

Figure 3. The distribution of the attendance, project, mid-term test and final test

\section{Analysis of Mean Difference}

Gender to Acbievement. The independent sample t-test was conducted in order to reveal whether there is a significant mean difference between boys and girls in the Literature Study course achievement. The results indicate that girls have a greater mean score in the Literature Study achievement. Table 2 presents the result of the mean difference analysis.
Table 2. Mean difference analysis result

\begin{tabular}{|c|c|c|c|c|c|c|}
\hline \multirow{2}{*}{ Variable } & Gender & $\mathbf{N}$ & Mean & $\mathrm{S}$ & \multirow[t]{2}{*}{$\bar{T}$} & \multirow[t]{2}{*}{ Sig } \\
\hline & $\overline{\text { Girls }}$ & 58 & 73.03 & 11.12 & & \\
\hline \multirow{2}{*}{ Final } & Boys & 32 & 72.22 & 10.98 & \multirow[t]{2}{*}{-3.74} & \multirow[t]{2}{*}{.00} \\
\hline & Girls & 58 & 81.45 & 11.34 & & \\
\hline
\end{tabular}

\section{Path Analysis}

A regression analysis was conducted in order to investigate the predictors of attendance, project presentation, mid-term test, and also final test (dependent variable). There were two independent variables: gender and class. Both of the independent variables were categorical data; gender consisted of two categories (boys and girls), while class consists of three categories (X, Y, and $\mathrm{Z})$. The predictor that consisted of three categories could not be simply categorized into 0 and 1 , so that a dummy variable needed to be created. A dummy variable is a way to represent groups of people or condition using only zero and one, and the number of dummy variables is one less than the number of the groups recoded (Field, 2013). The final model is shown in Figure 4.

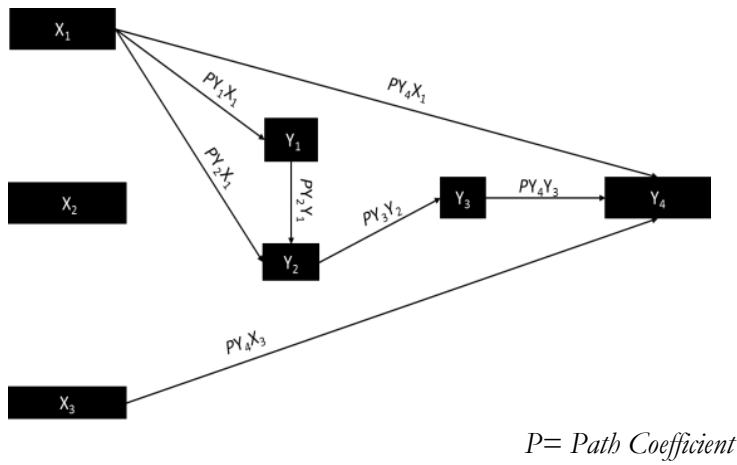

X1: Gender; X2: Classdummy1; X3: Classdummy2 Y1: Attendance; Y2: Project Presentation; Y3: Mid-term Test; Y4: Final Test

Figure 4. Research's final model

Pedhazur (1997) explains that in simple regression, $\beta$ is equal to correlation coefficient (r). He also mentions that the path coefficient from variable 1 to variable 2 is equal to $\beta_{21}$, which can be estimated from the data by calculating $r_{12}$. Thus, in this research, the coefficient for each path is clearly presented in Table 3. 
Table 3. Path coefficients

\begin{tabular}{|c|c|c|c|}
\hline \multirow{2}{*}{$\begin{array}{c}\text { Path } \\
\text { Coefficient } \\
(P)\end{array}$} & \multicolumn{2}{|c|}{ Unstandardized } & \multirow{2}{*}{$\begin{array}{c}\text { Standardized } \\
(\beta)\end{array}$} \\
\hline & $\mathbf{A}$ & B & \\
\hline $\mathbf{P Y}_{1} \mathbf{X}_{1}$ & 95.414 & $-4.226 \mathrm{X}_{1}$ & $-.270 \mathrm{X}_{1}$ \\
\hline $\mathbf{P Y}_{2} \mathrm{X}_{1}$ & \multirow{2}{*}{47.513} & $-2.430 \mathrm{X}_{1}$ & $-.199 \mathrm{X}_{1}$ \\
\hline $\mathbf{P Y}_{2} \mathbf{Y}_{1}$ & & $+.352 \mathrm{Y}_{1}$ & $.452 \mathrm{Y}_{1}$ \\
\hline $\mathrm{PY}_{3} \mathbf{Y}_{2}$ & 15.146 & $+.702 Y_{2}$ & $.370 \mathrm{Y}_{2}$ \\
\hline $\mathrm{PY}_{4} \mathrm{X}_{1}$ & \multirow{3}{*}{54.627} & $-7.685 X_{1}$ & $-.308 \mathrm{X}_{1}$ \\
\hline $\mathrm{PY}_{4} \mathrm{X}_{3}$ & & $-6.499 \mathrm{X}_{3}$ & $-.259 \mathrm{X}_{3}$ \\
\hline $\mathrm{PY}_{4} \mathrm{Y}_{3}$ & & $.401 \mathrm{Y}_{3}$ & $.372 \mathrm{Y}_{3}$ \\
\hline
\end{tabular}

Gender and Classes on Attendance. The result of the multiple regressions using the stepwise method to investigate the predictors of Attendance shows that gender is the only independent variable that is statistically significant in predicting the attendance. There are $7.3 \%$ attendance variances explained by gender. The equation used to predict students' attendance is as follows:

$$
\mathbf{Y}_{1}=P \mathbf{Y}_{1} \mathrm{X}_{1}
$$

Gender, Classes and Attendance on Project Presentation. Investigation was conducted using multiple regressions to find out the variables which predict project presentation. The result shows that $29 \%$ variances of project presentation are accounted by gender, classes, and attendance. The analysis found that gender and attendance are statistically significant to predict the students' project presentation score $(<.05)$, while classes are not significant $(>.05)$.

Unlike the previous multiple regression equation, the equation used to predict the students' project presentation considered both direct effect (gender on project presentation) and indirect effect (gender on project presentation through attendance) using the path analysis. In the path analysis, the sum of the direct effect and indirect effect is called the total effect, or effect coefficient (Pedhazur, 1997). The equation to predict the students' project presentation is as follows:

$$
\mathrm{Y}_{2}=\mathrm{PY}_{2} \mathrm{X}_{1}+\left(\mathrm{PY}_{1} \mathrm{X}_{1} * \mathrm{PY}_{2} \mathrm{Y}_{1}\right)
$$

Gender, Classes, Attendance, and Project Presentation on Mid-term Test. Another multiple regression analysis was conducted in order to investigate the predictors of students' midterm test scores. The analysis result indicated that gender, classes, attendance, and project presentation are able to explain $13.7 \%$ variances of students' mid-term test score, but only project presentation is statistically significant in predicting mid-term test $(<.05)$. The equation which was used to predict the students' mid-term test score has no direct effect, so the equation is constructed only by considering the indirect effects of: (1) gender on mid-term test through project presentation, and (2) gender on mid-term test through attendance and project presentation. The equation is as follows:

$$
\begin{gathered}
\mathbf{Y}_{3}=\left(\mathrm{PY}_{1} \mathrm{X}_{1} * \mathrm{PY}_{3} \mathrm{Y}_{2}\right)+\left(\mathrm{PY}_{1} \mathrm{X}_{1} * \mathrm{PY}_{2} \mathrm{Y}_{1} *\right. \\
\left.\mathrm{PY}_{3} \mathrm{Y}_{2}\right)
\end{gathered}
$$

Gender, Classes, Attendance, Project Presentation, Mid-term Test on Final Test. The last multiple regressions conducted was to find out which independent variables (gender, classes, attendance, project presentation, and midterm test) are able to predict students' final test score. The result shows that there are $33.4 \%$ variances of students' final test scores which are accounted by gender, classes, attendance, project presentation, and mid-term test result, but only mid-term test, gender and also classdummy2 (second dummy coding variable for classes) that are statistically proven as a significant predictors of students' final test scores. The equation was constructed by considering the direct effects (gender on final test and classdummy 2 on final-test) and indirect effects (gender on final test through project presentation and mid-term test, and also gender on final test through attendance, project presentation and mid-term test). The equation which is used to predict students' final test score is as follows:

$$
\begin{gathered}
\mathrm{Y}_{4}=\mathrm{PY}_{4} \mathrm{X}_{1}+\mathrm{PY}_{4} \mathrm{X}_{3}+\left(\left(\mathrm{PY}_{2} \mathrm{X}_{1} * \mathrm{PY}_{3} \mathrm{Y}_{2} *\right.\right. \\
\left.\left.\mathrm{PY}_{4} \mathrm{Y}_{3}\right)+\left(\mathrm{PY}_{1} \mathrm{X}_{1} * \mathrm{PY}_{2} \mathrm{Y}_{1} * \mathrm{PY}_{3} \mathrm{Y}_{2} * \mathrm{PY}_{4} \mathrm{Y}_{3}\right)\right)
\end{gathered}
$$

Predicting Final Test Score in Different Classes. Every class has its own characteristics influenced by the students' environmental and academic background. The idea of the differ- 
ent characteristics of class leads to a further analysis to compare the contribution of each predictor in different classes. Table 4 shows the result of the multiple regressions using the enter method in each class.

Table 4. Comparing the effects of gender, attendance, project, mid-term test on final test in different classes

\begin{tabular}{cccc}
\hline \multirow{2}{*}{ Predictors } & \multicolumn{3}{c}{ Final Test } \\
\cline { 2 - 4 } & $\mathbf{X}$ & $\mathbf{Y}$ & $\mathbf{Z}$ \\
\hline Gender & $-.502^{*}$ & -.171 & -.275 \\
Attendance & $.067^{*}$ & .228 & -.388 \\
Project & -.122 & .102 & .386 \\
Presentation & & & \\
Mid-term test & $.399^{*}$ & .348 & .317 \\
\hline $\mathrm{R}_{2}$ & .495 & .434 & .337 \\
\hline $\mathrm{E}$ & .505 & .566 & .663 \\
\hline $\mathrm{N}$ & 25 & 34 & 31 \\
\hline & & & $\mathrm{P}<.05$
\end{tabular}

The result shows that in Class $1(\mathrm{X})$, the biggest predictor is gender and the lowest one is attendance. In class $\mathrm{Y}$, the biggest predictor of the students' final test is mid-term test score, and the lowest predictor is project presentation. In class $\mathrm{Z}$, the biggest predictor of students' final test is attendance, while the lowest one is gender. The result proves that the predictors might predict the independent variable in different magnitude based on the class characteristics. Due to the different magnitude of the predictors, it is recommended that lecturers treat the classes differently.

\section{Discussion}

The research findings show that girls have a significantly greater mean score than boys in terms of Literature Study achievement. In line with the mean difference analysis result, the final model of this study also shows the contribution of gender to students' final achievement. Two previous researchers, Downing (1977) and Droege (1967), mention that girls have greater facility in early reading skill. The evidence of girls' reading ability is also revealed by Finucci, Gottfredson, and Childs (1985). Based on the reserach, women become better oral readers, buy more books, and read more pleasure than men.

Beside the direct contribution to students' achievement, gender is also found to be the predictor of students' attendance rate and project persentation performance. Based on the lecturer reports, girls tend to attend the class more often than boys, and girls are more serious in doing their project persentation homework. In line with this, the research of Duckworth and Seligman (2005, p. 939) also explains that girls are more self-disciplined than boys in final grades, school attendance, and hours-spending homeworks.

Unlike gender, the first dummy variable $(X=0, Y=1$, and $Z=0)$ has no significant effect on any independent variables. The second dummy variable $(\mathrm{X}=0, \mathrm{Y}=0$, and $\mathrm{Z}=1)$ has a direct negative significant effect on students' achievement. It means that class $Z$ has significantly lower achievement compared to the other classess (X and Y). Based on the predictor analysis conducted for each class, the low achievement of class $\mathrm{Z}$ was due to the low score of students' attendance.

Students' attendance, which is influenced by gender, is statistically proven as the predictor of the students' project presentation performance. Attendance is also found to be the indirect predictor of final achievement through the project presentation and midterm test score. The previous research also found a similiar phenomenon. The research of Deane and Murphy (2013) found that the students' attendance is positively correlated with overall examination score. In addition, Louis, Bastian, McKimmie, and Lee (2016) also found the positive correlation between attendance and objective performance.

\section{Conclusion and Suggestions}

\section{Conclusion}

Based on the findings, conclusions can be drawn as follows: (1) girls have higher achievement in Literarture Study compared to boys; (2) the predictors which are statistically proven as direct significant predictors of students' final test score are gender, second dummy variable for class, and mid-term test, while the rest of the predictors (except for the first dummy variable of class) contribute indirectly to predicting students' achievement in Literature Study; (3) the magnitude of the predictors might be different in different classes. 
Limitation of the Research

The limitation of the research is that: (1) the research was conducted in an Islamic Institution, in which the references studied in the Literature Study course are those related to the Islamic religion education, prophetic character, and intellectual character; (2) every institution has their own policy related to what kind of academic activities that the students have to pass through during Literature Study course in one semester.

\section{Suggestions}

To achieve optimum final test score in Literature Study, the lecturers are suggested to: (1) consider gender, class, attendance, project presentation score, and mid-term test score to improve students' final test score; (2) be concerned with the mid-term test results, because only mid-term test has a direct effect on the final test score; and (3) treat each class differently based on their own characteristics.

\section{References}

Berg, S. L. (2006). Two sides of the same coin: Authentic assessment. Community College Enterprise, 12(2), 7-21. Retrieved from https://www.questia.com/read/1 P3-1167542141/two-sides-of-the-samecoin-authentic-assessment

Cumming, J. J., \& Maxwell, G. S. (1999). Contextualising authentic assessment. Assessment in Education: Principles, Policy \& Practice, 6(2), 177-194. https://doi. org/10.1080/09695949992865

Deane, R. P., \& Murphy, D. J. (2013). Student attendance and academic performance in undergraduate obstetrics/gynecology clinical rotations. $J A M A, 310(21)$, 2282-2288. https://doi.org/10.1001/ jama.2013.282228

Downing, J. (1977). How society creates reading disability. The Elementary School Journal, 77(4), 274-279. https://doi.org /10.1086/461058

Droege, R. C. (1967). Sex differences in aptitude maturation during high school.
Journal of Counseling Psychology, 14(5), 407-411.

Duckworth, A. L., \& Seligman, M. E. P. (2005). Self-discipline outdoes IQ in predicting academic performance of adolescents. Psychological Science, 16(12), 939-944. https://doi.org/10.1111/j.14 67-9280.2005.01641.x

Field, A. P. (2013). Discovering statistics using IBM SPSS statistics (4th ed.). Los Angeles, CA: Sage Publication.

Finucci, J. M., Gottfredson, L. S., \& Childs, B. (1985). A follow-up study of dyslexic boys. Annals of Dyslexia, 35(1), 117-136. https://doi.org/10.1007/BF02659183

Louis, W. R., Bastian, B., McKimmie, B., \& Lee, A. J. (2016). Teaching psychology in Australia: Does class attendance matter for performance? Australian Journal of Psychology, 68(1), 47-51. https://doi.org/10.1111/ajpy.12088

Miller, M. D., Linn, R. L., \& Gronlund, N. E. (2009). Measurement and assessment in teaching (10th ed.). Upper Saddle River, NJ: Pearson.

Pedhazur, E. J. (1997). Multiple regression in behavioral research: Explanation and prediction (3rd ed.). Orlando, FL: Harcourt Brace College.

Phye, G. D. (Ed.). (1995). Handbook of classroom assessment: Learning, achievement, and adjustment. Ames, IA: Academic Press.

Pritchard, A. (2009). Ways of learning: Learning theories and learning styles in the classroom (2nd ed.). Oxford: Routledge.

Reynolds, C. R., Livingston, R. B., \& Willson, V. L. (2009). Measurement and assessment in education (2nd ed.). Upper Saddle River, NJ: Pearson.

Thorndike, R. M., \& Thorndike-Christ, T. M. (2010). Measurement and evaluation in psychology and education (8th ed.). Boston, MA: Pearson Education. 